\title{
Corrigendum: Ankylosing Spondylitis Patients Have Impaired Osteoclast Gene Expression in Circulating Osteoclast Precursors
}

\author{
Inês P. Perpétuo ${ }^{1 *}$, Joana Caetano-Lopes ${ }^{1}$, Elsa Vieira-Sousa ${ }^{1,2}$, \\ Raquel Campanilho-Marques ${ }^{1,2}$, Cristina Ponte ${ }^{1,2}$, Nikita Khmelinskii ${ }^{2}$, Helena Canhão ${ }^{3}$, \\ Mari Ainola ${ }^{4}$ and João E. Fonseca ${ }^{1,2}$ \\ ${ }^{1}$ Rheumatology Research Unit, Faculdade de Medicina, Instituto de Medicina Molecular, Universidade de Lisboa, Lisboa, \\ Portugal, ${ }^{2}$ Rheumatology Department, Hospital de Santa Maria, Centro Hospitalar Lisboa Norte, EPE, Lisbon Academic \\ Medical Centre, Lisboa, Portugal, ${ }^{3}$ EpiDoC Unit, Chronic Diseases Research Center (CEDOC), NOVA Medical School, \\ Universidade Nova de Lisboa, Lisboa, Portugal, ${ }^{4}$ Musculoskeletal Diseases and Inflammation Research Group, Biomedicum \\ Helsinki 1, Faculty of Medicine, Institute of Clinical Medicine, University of Helsinki, Helsinki, Finland
}

Keywords: monocytes, osteoclasts, ankylosing spondylitis, CSF1R, RANK, NFATc1, gene expression, humans

\section{OPEN ACCESS}

Edited and Reviewed by: Xenofon Baraliakos, Ruhr-University Bochum, Germany

*Correspondence: Inês P. Perpétuo ines.perpetuo@gmail.com

Specialty section: This article was submitted to Rheumatology,

a section of the journal

Frontiers in Medicine

Received: 12 March 2017 Accepted: 21 March 2017 Published: 12 April 2017

Citation: Perpétuo IP, Caetano-Lopes J,

Vieira-Sousa E, CampanilhoMarques R, Ponte C, Khmelinskii N, Canhão H, Ainola M and Fonseca JE (2017) Corrigendum: Ankylosing Spondylitis Patients Have Impaired Osteoclast Gene Expression in Circulating Osteoclast Precursors. Front. Med. 4:38.

doi: 10.3389/fmed.2017.00038

\section{A corrigendum on}

Ankylosing Spondylitis Patients, Have Impaired Osteoclast Gene Expression in Circulating Osteoclast Precursors

by Perpétuo IP, Caetano-Lopes J, Vieira-Sousa E, Campanilho-Marques R, Ponte C, Khmelinskii N, et al. Front Med (2017) 4:5. doi: 10.3389/fmed.2017.00005

In the original article, the name of the author Nikita Khmelinskii was missing by mistake. The authors apologize for this oversight.

\section{New Author Contribution Statement:}

Conceived and designed the experiments: IP, JC-L, HC, MA, and JF. Performed the experiments: IP and JC-L. Analyzed the data: IP, JC-L, RC-M, CP, NK, EV-S, and HC. Contributed reagents/ materials/analysis tools: IP, RC-M, CP, EV-S, NK and HC. Wrote, reviewed, and accepted the final version of the paper: IP, JC-L, RC-M, CP, EV-S, NK, HC, MA, and JF.

These errors do not change the scientific conclusions of the article in any way.

The original article has been updated.

Conflict of Interest Statement: The authors declare that the research was conducted in the absence of any commercial or financial relationships that could be construed as a potential conflict of interest.

Copyright (c) 2017 Perpétuo, Caetano-Lopes, Vieira-Sousa, Campanilho-Marques, Ponte, Khmelinskii, Canhão, Ainola and Fonseca. This is an open-access article distributed under the terms of the Creative Commons Attribution License (CC BY). The use, distribution or reproduction in other forums is permitted, provided the original author(s) or licensor are credited and that the original publication in this journal is cited, in accordance with accepted academic practice. No use, distribution or reproduction is permitted which does not comply with these terms. 